\title{
Esophageal Cancer Metastases to Unexpected Sites: A Systematic Review
}

\author{
Osama Shaheen, ${ }^{1}$ Abdulaziz Ghibour, ${ }^{1}$ and Bayan Alsaid ${ }^{1,2}$ \\ ${ }^{1}$ Department of General Surgery, Damascus University Hospitals, Faculty of Medicine, Damascus University, Damascus, Syria \\ ${ }^{2}$ Laboratory of Anatomy, Faculty of Medicine, Damascus University, Damascus, Syria
}

Correspondence should be addressed to Bayan Alsaid; drbayan@gmail.com

Received 12 March 2017; Accepted 24 April 2017; Published 4 June 2017

Academic Editor: Yusuke Sato

Copyright ( 2017 Osama Shaheen et al. This is an open access article distributed under the Creative Commons Attribution License, which permits unrestricted use, distribution, and reproduction in any medium, provided the original work is properly cited.

\begin{abstract}
The most common pattern of esophageal cancer metastases (ECM) is to the lymph nodes, lung, liver, bones, adrenal glands, and brain. On the other hand, unexpected metastasis (UM) spread to uncommon sites has increasingly reported and consequently affected the pathway of diagnosis, staging, and management. Using the PubMed database, a systematic search of the following headings "Esophageal" and "Metastasis" or "Metastases" was performed, 10049 articles were identified, and the articles were included if they demonstrated unexpected ECM. 84\% of cases were men with an average age of 60.7 years. EC was located in the lower third in $65 \%$. Two-thirds of the UM originated from the lower esophagus, and the two major histological types were adenocarcinoma $40 \%$ and squamous cell carcinoma $60 \%$. Metastases were disseminated toward five main anatomical sites: the head and neck (42\%), thoracic (17\%), abdomen and pelvis (25\%), extremities (9\%), and multiple skin and muscle metastases (7\%). The EC metastases were found to be synchronous $42 \%$ and metachronous $58 \%$, isolated in $53.5 \%$ and multiple in $46.5 \%$. The overall survival rate was 10.2 months. Since distant metastases are responsible for most EC-related deaths, understanding of ECM dissemination patterns needs more extensive studies. These critical data are the cornerstone of optimal cancer approach and treatment.
\end{abstract}

\section{Introduction}

Esophageal cancer (EC) is one of the exceedingly aggressive cancer worldwide; hence, relatively, a scant number of articles was published trying to study EC distinctive features. The overall incidence of EC in the United States has been fairly stable for many years, with 5-year relative survival rate ranges between $40 \%$ for localized tumor (N0-M0) and $4 \%$ for advanced distal metastasis tumors (M1, [1-2]). Since distant metastasis represents the most common cause of cancerrelated death, secrets of EC cell dissemination constitute the most valuable key in optimal approaching of EC features.

Up until now, several studies have investigated the complexity of EC lymphogenic-hematologic metastasis patterns [3-5]. Clearly, EC locoregional and expected distal metastasis features have been widely studied. However, a distinct number of clinical articles have reported on the frequency of the unexpected esophageal cancer metastases (ECM).
Correspondingly, we reviewed and summarized the scientific literature on the unexpected ECM distribution, with the goal of achieving a closer insight about the tumor cell distribution principles, and help determining optimal cancer control strategies.

\section{Methods}

2.1. Study Population and Search Strategy. Between 1982 and February 2017 using the PubMed database (US National Library of Medicine, Bethesda, Maryland), a systematic medical literature search was conducted by the researchers to identify the articles describing uncommon ECM.

First, using the following key words "Esophageal" and "Metastasis" or "Metastases", 10049 articles were identified and additional 6 cases from other resources were identified and included. Second, the titles and abstracts of these articles were reviewed, the articles with expected metastases were 


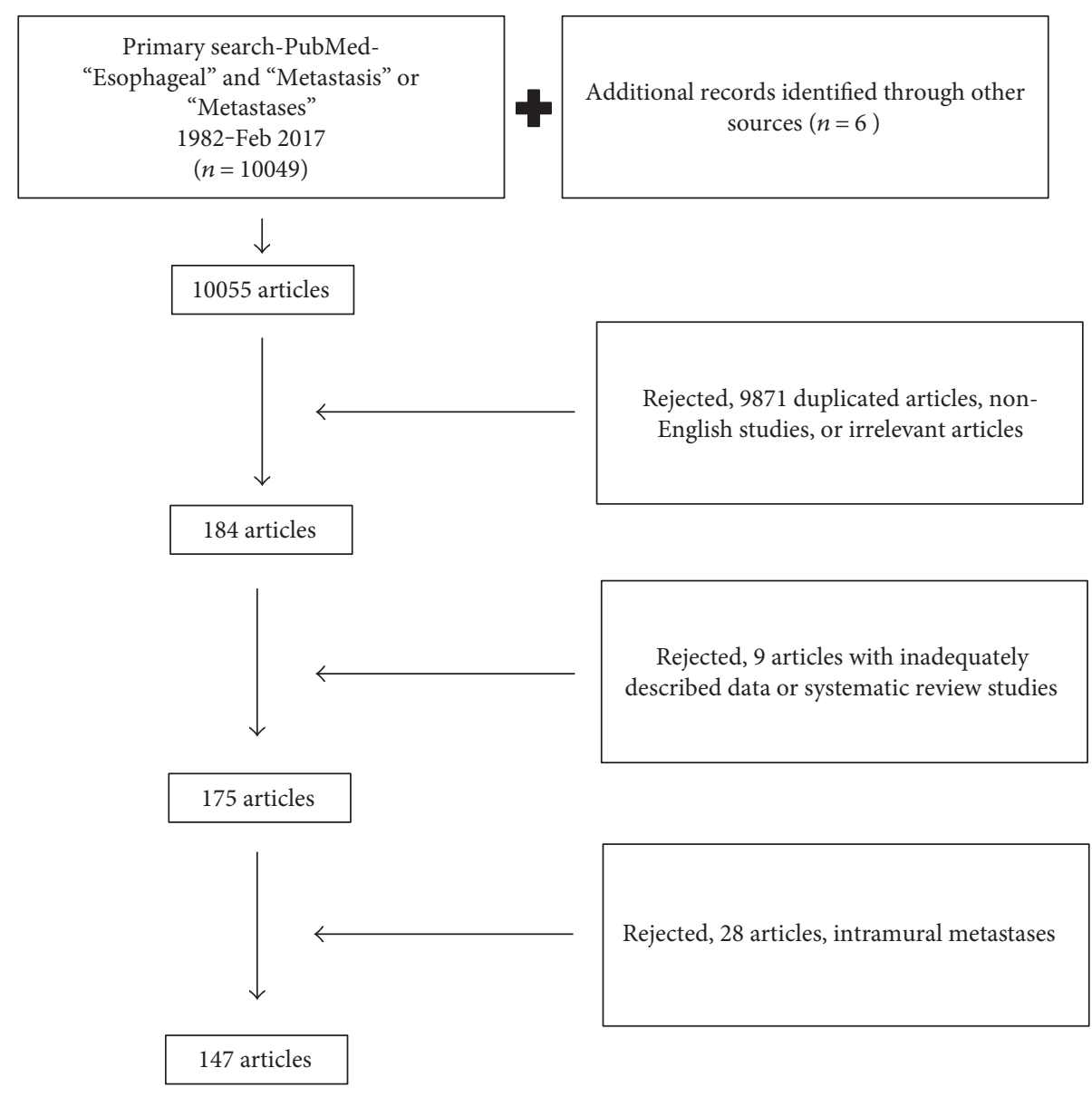

FIgURE 1: The selection process of the study.

dropped from the study, and the articles were included if they demonstrated case report or case series of unexpected ECM. Eventually, relevant articles were reviewed and sorted for final analyzation. Figure 1 represents the flow diagram for searching and extracting data (between 1982 and February 2017).

2.2. Selection Criteria. The systematic review started from a very broad search process to include every possible article. The next step limited our search only to English language original articles, case reports, case series, or editorial letters that described the unusual locations of ECM. Each of these organs was considered common metastasis sites and was dropped from the study: the liver, bone, lungs, adrenal glands, and brain. Since it has specific spread rout, the articles who described intramural metastases were also added to the exclusion criteria.

2.3. Selection of Data. The authors selected studies based on the titles or abstracts. Studies that met the inclusion criteria were selected for review. If it was not clear from the abstract whether a study fulfilled the inclusion criteria, the full article was retrieved for further evaluation.

2.4. Data Extraction and Quality Assessment of Included Material. In total, 164 cases (out of 147 articles) [6-153] of unexpected ECM were selected to establish our database. The following data elements were extracted from each article: author name, publication year, article type, patient sex, age at diagnosis, histological type of cancer, tumor location in the esophagus, stage at diagnosis, management of primary tumor, site of metastases, metastasis features (solitary, multiple, synchronous, metachronous, and onset after initial tumor diagnosis), management of metastases, outcomes, and survival.

Extracted data were treated in Excel table and validated by the three authors.

\section{Results}

3.1. Patient Characteristics. Between 1982 and February 2017, a total number of 164 patients were included in the study. Clinicopathological characteristics of EC with unexpected metastases were summarized in Table 1 . In general, $84 \%$ of the patients were male, $16 \%$ female, and the median age at diagnosis was 60.7-year-old with almost half of these cases were designated as stage IV upon the initial diagnosis. About two third of the unexpected metastases originated from the lower esophagus, and the two major histological types of the cancer were adenocarcinoma in $40 \%$ and squamous cell carcinoma in $60 \%$. 
TABLE 1: Clinicopathological characteristics of EC with unexpected metastases.

\begin{tabular}{lc}
\hline Demographics \& clinical features & EC with unexpected metastasis \\
\hline Age at diagnosis (median) & 60.7 \\
Gender/male & $84 \%$ \\
Gender/female & $16 \%$ \\
Histology/SCC & $60.5 \%$ \\
Histology/adenocarcinoma & $39.5 \%$ \\
Location/upper & $8 \%$ \\
Location/middle & $27 \%$ \\
Location/lower & $65 \%$ \\
Stage I & 8 \\
Stage II & 9 \\
Stage III & 31 \\
Stage IV & 52 \\
\hline
\end{tabular}

3.2. Anatomical Distribution of Unexpected Esophageal Cancer Metastases. Unexpected ECM tend to spread to different anatomical sites. For statistical analysis purposes, metastases were stratified according to five main anatomical sites (groups), the head and neck, abdominopelvic, thoracic, extremities, and multiple skin and muscle metastases (Figure 2). On the other hand, Figure 3 illustrates a different analytic scenario according to organ metastasis. For example, the skin, eye, muscle, and heart represented the most common $(13 \%, 12 \%, 9 \%$, and $7 \%$, resp.) organ metastases while the tonsillar, tongue, and cerebellum were scarcely reported (only one case each).

3.3. Esophageal Cancer Features across 5 Major Metastasis Anatomical Groups. In this study, we have evaluated the frequency of many EC primary features among metastasis major location.

First, regarding general metastasis anatomical groups, as illustrated in Figure 4, the head and neck metastases represented the most common unexpected metastases (42\%), with lower esophagus considered as the most frequent initial tumor location (66\%). On the other hand, upper EC constituted only $8 \%$ of initial tumor locations with the head, neck, and extremity regions represented $90 \%$ of its metastases.

Second, regarding organ metastasis stratification, in thoracic group, the heart and breast constitute the most common sites of UM, in abdominopelvic cavity group; UM were most common to the renal, pancreas, and spleen, in head and neck group; spread was most common to the eye, jaw, skull, and dura (Figure 3).

Third, considering tumor histological classification; as elucidated in Figure 5, SSC constituted $60 \%$ of cases in general. In the abdominopelvic and thoracic groups, SCC represented over $75 \%$ of cases. However, adenocarcinoma represented $60 \%$ of cases in the head and neck group and $50 \%$ in the multiple skin and muscles group.

Fourth, the relation between metastasis anatomical groups and initial cancer stage was demonstrated in

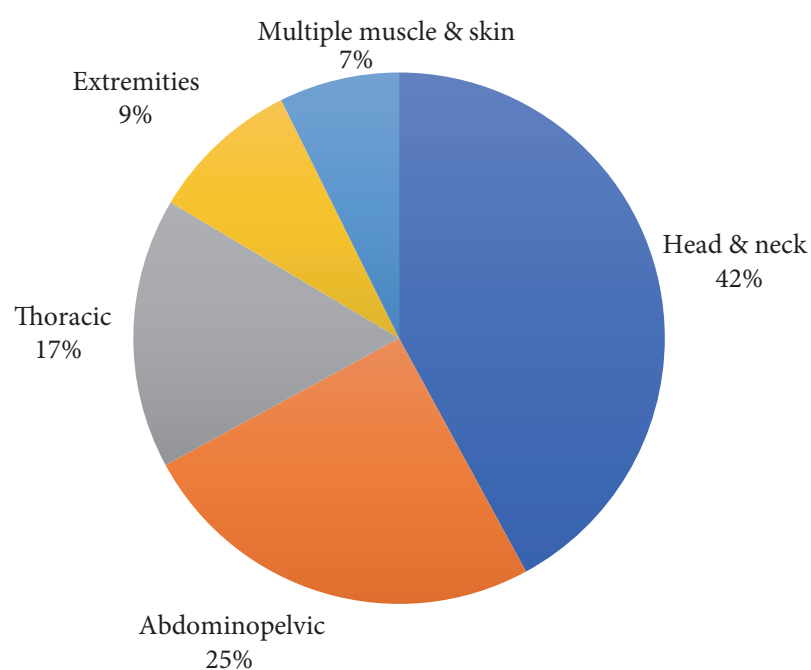

FIgURE 2: Unexpected ECM stratification according to anatomical site spread.

Figure 6, and it showed that in general, $83 \%$ of cases were initially diagnosed as stage III or IV. However, in the thoracic group, $42 \%$ of cases were stage I or II, and in multiple metastasis group, $100 \%$ of cases were stage IV.

3.4. Cancer-Metastasis Synchronizations. As an important variable, we investigated the probability of cancermetastasis synchronization in different anatomical groups. As shown in Figure 7, in general, metastases were diagnosed at the same time with the initial tumor in $42 \%$ of cases, and interestingly, this rate approaches $91 \%$ in multiple metastasis group and sometimes were the first symptoms of the tumor. On the other hand, metastases were metachronous in $58 \%$ in cases ( $72 \%$ in the extremities group) and the median interval time between initial tumor and metastasis diagnosis was 8.3 months ( 4.5 months in the extremity group versus 13 months in the abdominopelvic group).

3.5. Metastasis Approaching and Lifetime Prognosis. Finally, we investigated the metastasis evaluation process and the influence of the metastasis location on lifetime prognosis. It was important to know (as shown in Figure 8) that 54\% of the UM were isolated upon diagnosis and this trend reached $70 \%$ in the extremity and abdominopelvic groups; on the other hand, this rate was only $37 \%$ in the head and neck group.

The analysis of the metastasis management plan based on location was demonstrated in Figure 9 and notably showed that in general, surgery was part of the management plan in $44 \%$ of cases and no management was applicable in $17 \%$ of cases. However, when considering anatomical groups, surgery was available in $70 \%$ of the abdominopelvic group and no management was applied in $37 \%$ of the thoracic group.

The influence of both metastasis anatomical location and cancer-metastasis synchronization on the total outcome was shown in Figure 9. Regarding synchronization, the survival rate was 13 months in synchronous group versus 6.1 months 


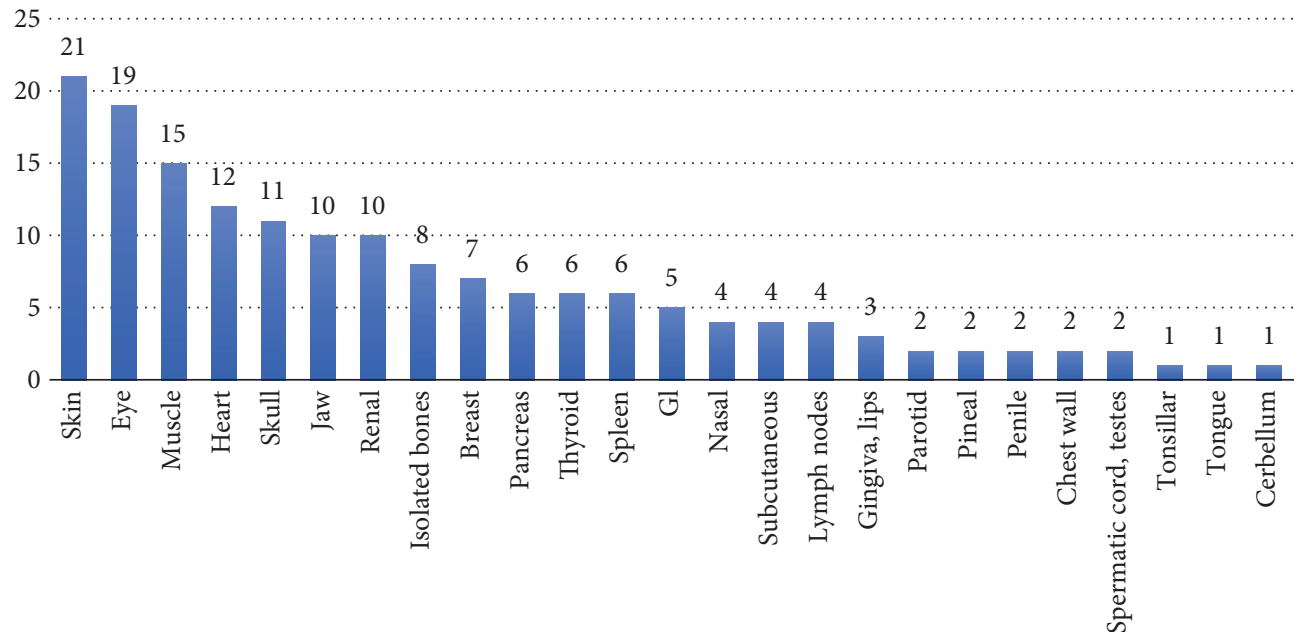

FIGURE 3: Unexpected ECM trend across organs.

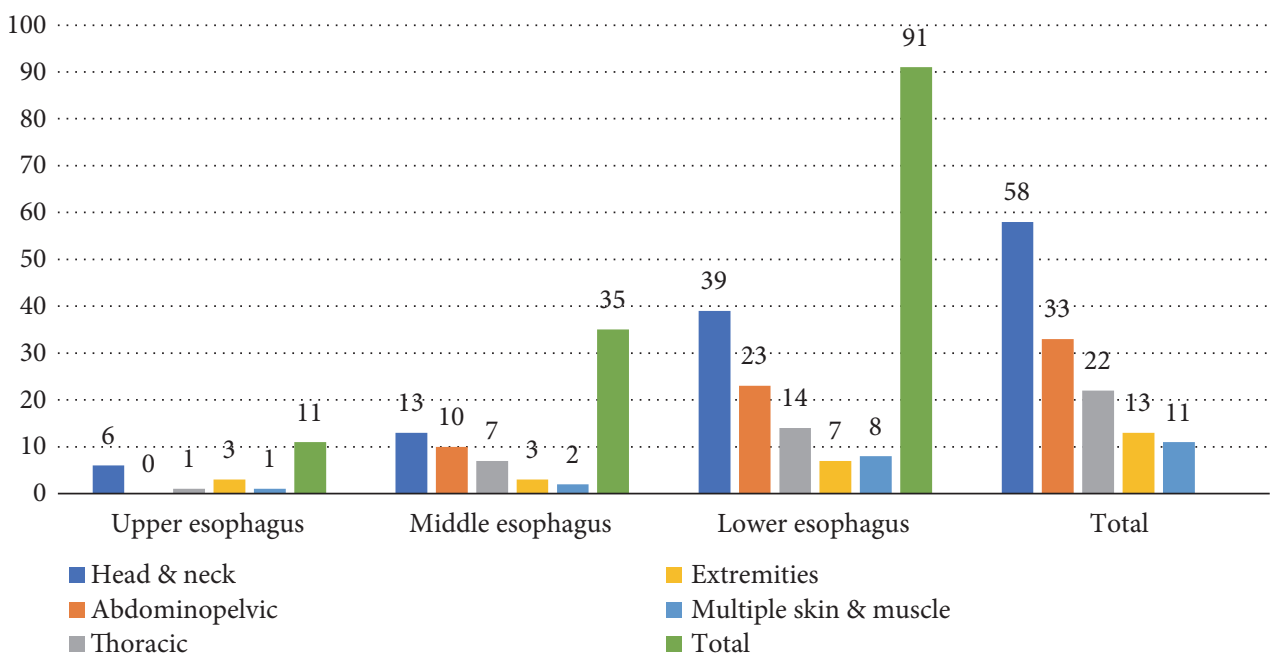

(a)

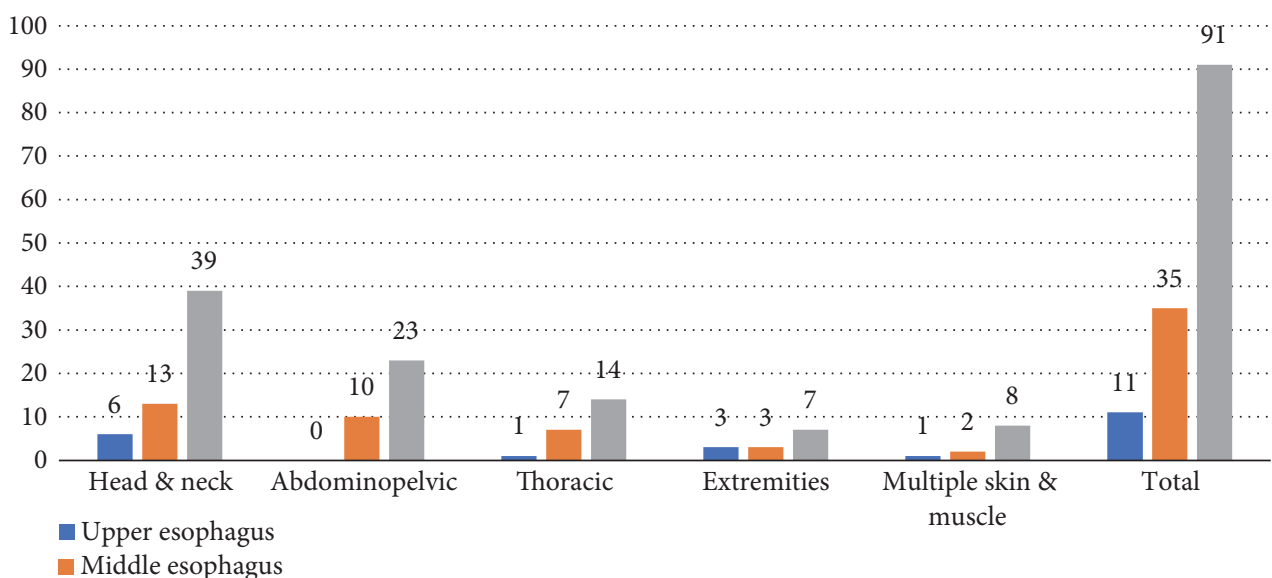

iddle esophagus

(b)

FIgURE 4: (a) Primary EC location influence on metastasis distribution. (b) Metastasis trend according to primary EC location. 


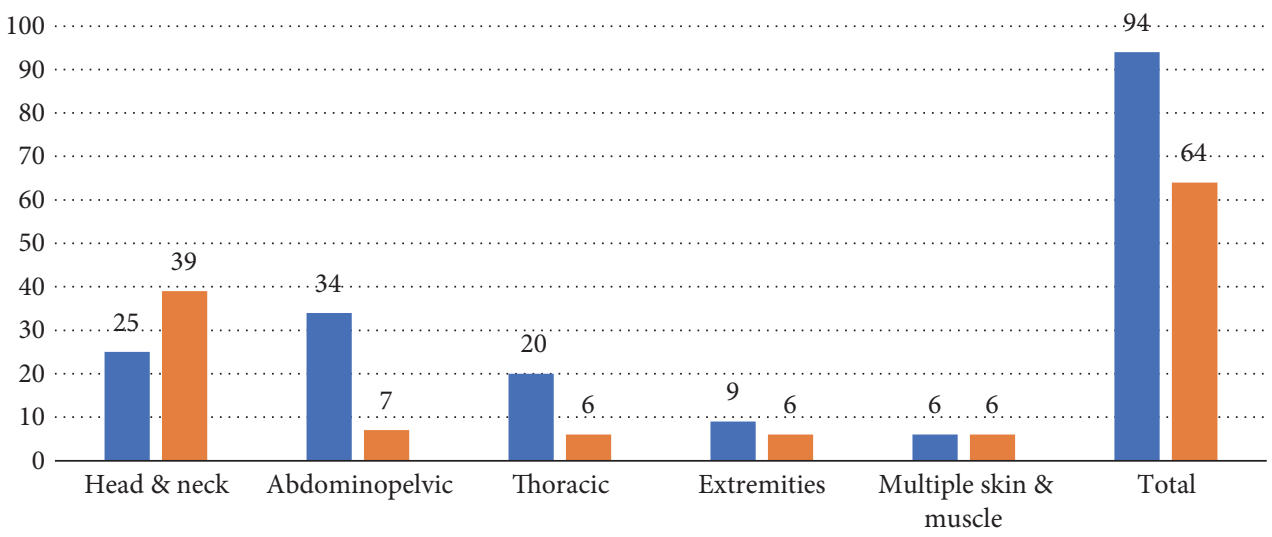

$\square$ SCC

- Adenocarcinoma

FIgURE 5: ECM anatomic location influence on pathological rate.

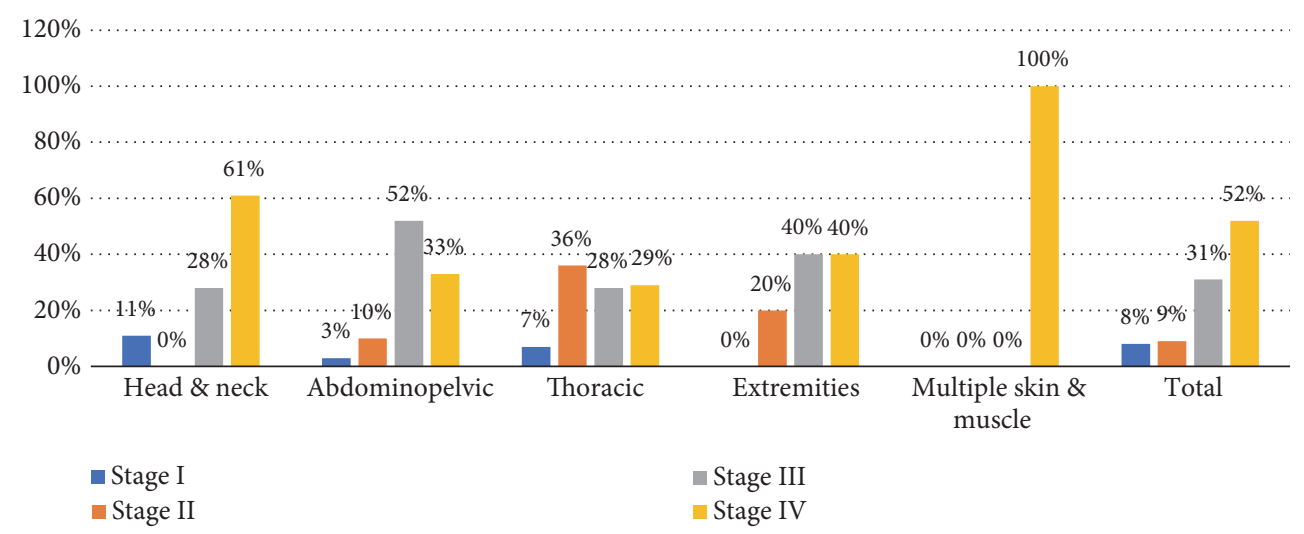

FIGURE 6: Tumor stage trend upon diagnosis among different ECM anatomical locations.

in the metachronous group. From a different standpoint, survival rate approached 16 months in the abdominopelvic group versus 4 months in the multiple skin and muscle metastasis group.

\section{Discussion}

Historically, cancer-distal metastases have been always considered the most potential barrier in achieving a significant advance in cancer management. In addition, being responsible for $90 \%$ of cancer-related deaths [154, 155], the question of how tumor cells metastasize across different anatomical sites has the key role in establishing optimal cancer-approaching plan.

Remarkably, the impact of esophageal cancer regional and usual distal metastases on survival and outcome has been widely studied in various, well-controlled studies. On the other hand, unexpected metastases have been only investigated through sporadic case reports and small caseseries studies.

Here, in this study, we have determined esophageal cancer-unexpected metastasis features and have investigated their clinicopathological variations across different anatomical site distribution.

Our study demonstrated that EC has a special tendency for unexpected specific site expansion, and this behavior has been attributed to the unique anatomical esophageal features which considered a key player in elucidating EC distinctive and extremely aggressive nature.

As already known, the absence of serosal coating and the presence of periesophageal adventitia that connects it with the mediastinum structures including the recently discovered aorto-esophageal ligament [156] have an important impact on the lymph node metastasis frequency and tumor ingrowth into the surrounding and distal organs.

These unique features can also be partly attributed to its multiple arterial resources (shared vasculature), starting from the inferior thyroid artery to the splenic artery across different arterial supplies between them. Moreover, the esophagus extrinsic veins drain into the locally corresponding large vessels (the jugular veins or the azygos and hemizygous veins superiorly and to the left gastric and splenic veins inferiorly). Interestingly, having penetrated the muscular wall, the small vessels form abundant submucosal plexus which could 


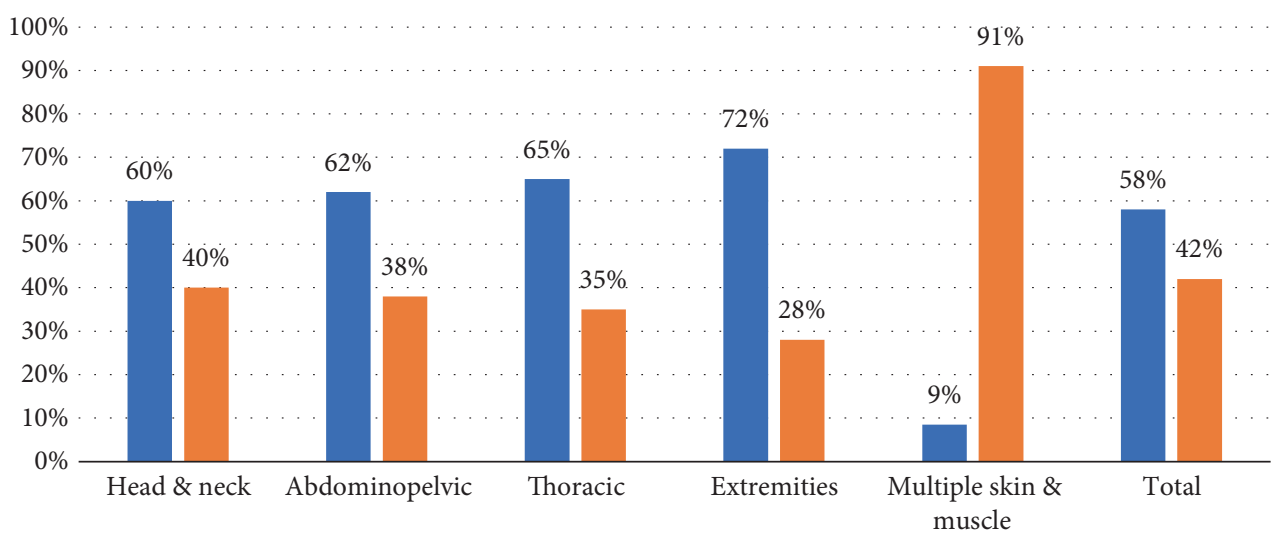

- Timing: metachronous (rate)

- Timing: synchronous (rate)

(a)

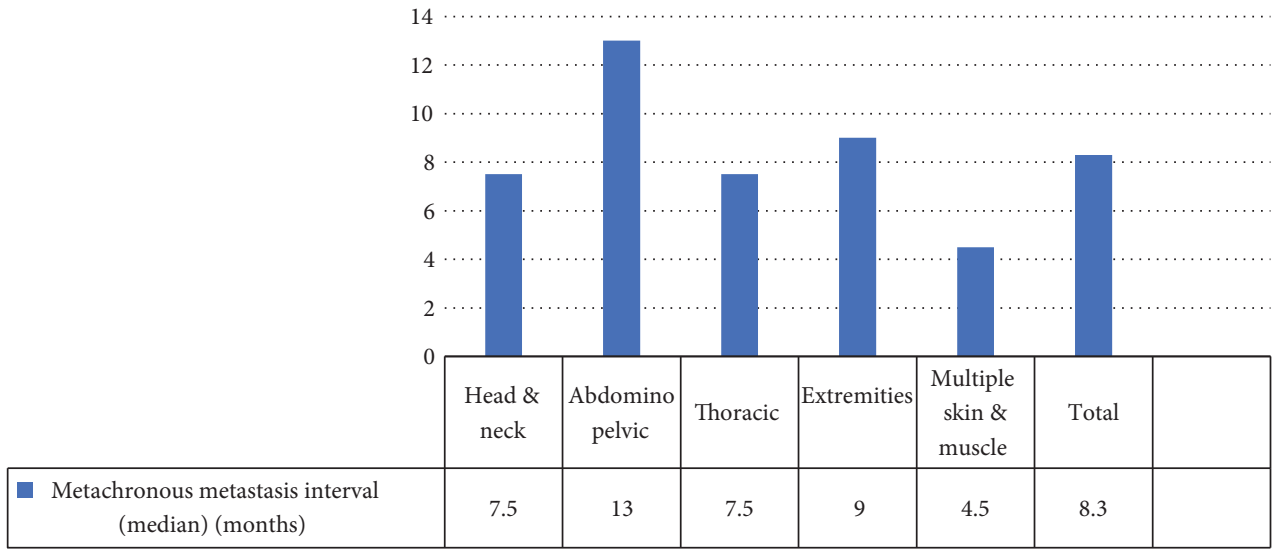

(b)

Figure 7: (a) Cancer-metastasis onset (metachronous and synchronous) across ECM anatomical groups. (b) EC and metastasis interval (median and months).

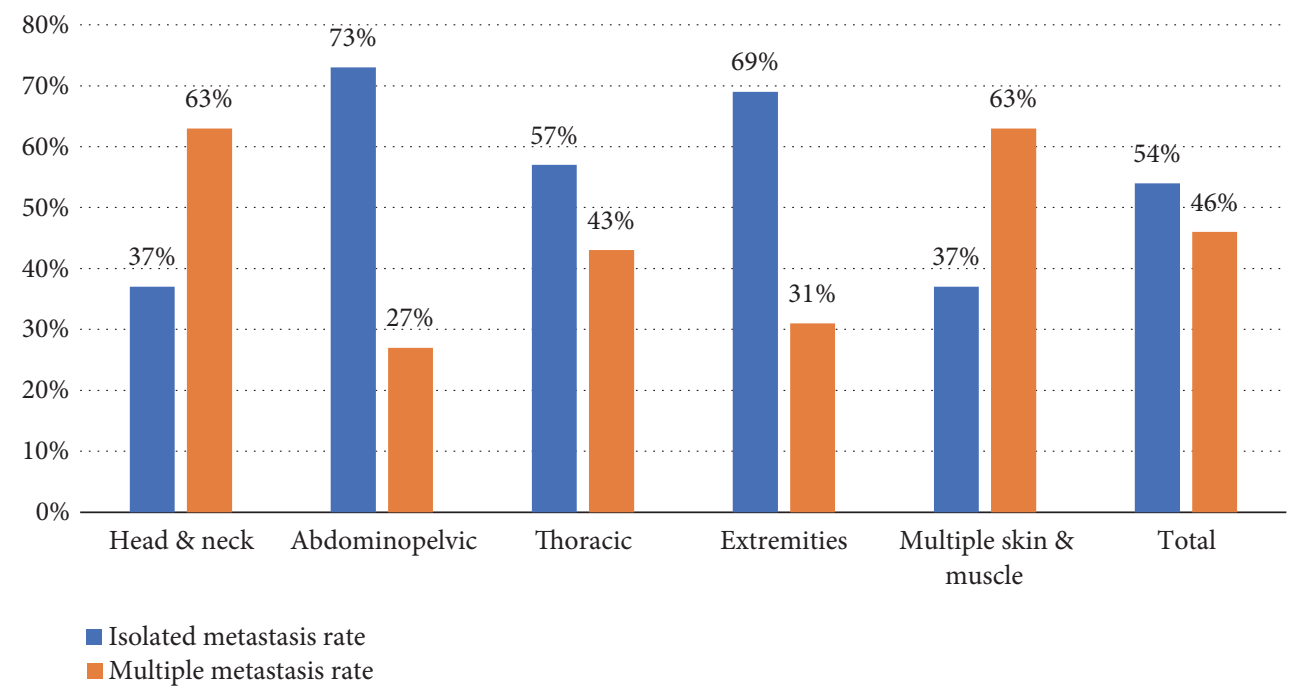

Figure 8: Metastasis features (isolated versus multiple). 


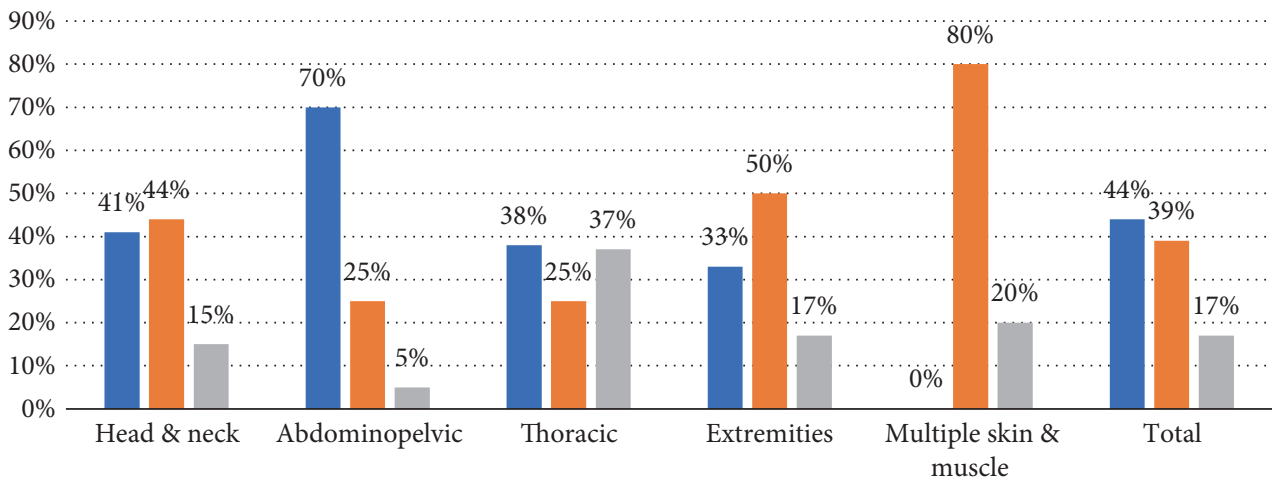

- Mets management rate (surgery, chemotherapy, radiation)

Mets management rate (chemotherapy, radiation)

No management

(a)

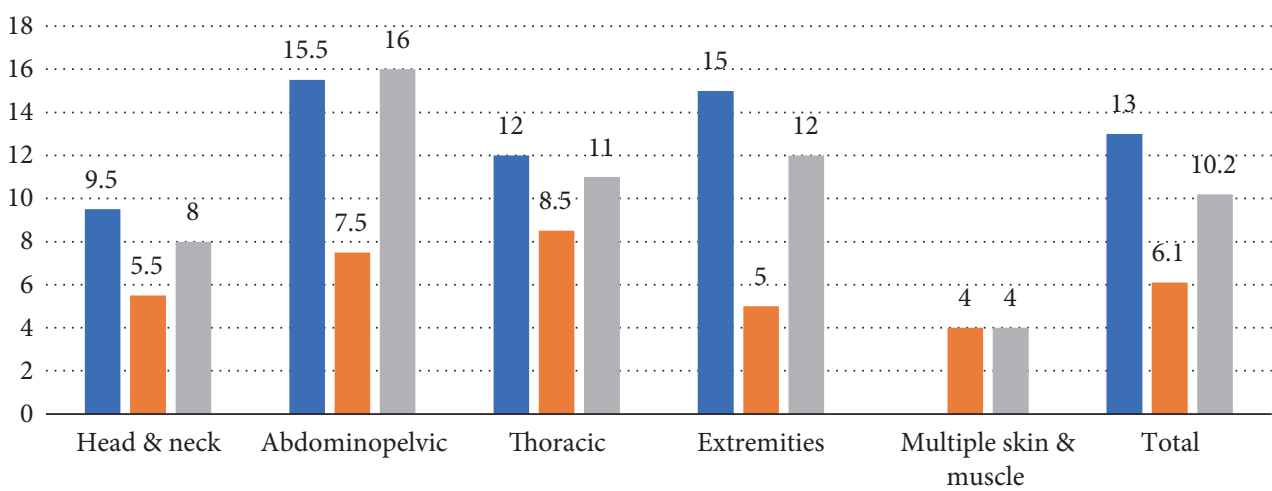

Synchronous mets, outcome \& survival (months, median)

Metachronous mets, outcome \& survival (months, median)

Total outcome \& survival (months, median)

(b)

Figure 9: (a) Metastasis management. (b) Outcome and survival.

explain the existence of distal unexpected metastases in some patient with low-stage cancer (1 or 2).

Furthermore, the complex anatomical pathway of the esophagus lymphatic network including the lymphatic nodal skip (retrograde and bidirectional) spread [156-158] can also explain the possibility of the random distribution of the metastases in esophagus cancer.

In this context, based on hematologic and lymphatic anatomy, EC distant metastases can leave the esophagus via three possibilities: lymphatic, venal, or arterial routs. The venal routes will pass in the vena cava then the pulmonary system explaining the standard pulmonary metastases, or in the portal system explaining the hepatic metastases [159]. However, the isolated distal metastases in terminal organs or anatomical structures such as the skin, penis, lips, or retina can be hardly explained based on lymphatic or venal routs alone. Even though tumors almost always metastasize through the veins rather than through the arteries, the expected route of those unexpected metastases may be explained by the arterial pathway. In support of the former possibility, arterial blood has been proved to be a better source of circulating tumor cells than venous blood [160].
The lymphatic route could explain the invasion to the neighboring anatomical structure such as the neck, mediastinum, or gastric localization. The phenomena of retrograde lymph drainage due to intramural lymph vessel obstruction [161] could explain some distal intramural metastases; however, the distal isolated metastases are still poorly supported via this route.

In our opinion, the arterial route could be the way in which this tumor embolism liberates and pass toward the main artery to follow an anatomical direction and finally reach the distal terminal organs. Our observations could reinforce this proposition as some metastases were isolated, metachronous with no recurrence of the primary tumor. This anatomical hypothesis can be added to different beyond anatomical hypotheses where either certain molecular features acquired during tumor evolution serve as one master key for distinct locks or the microenvironment of two host organs resemble each other thereby equally facilitating metastasis in two anatomically distinct locations [162].

Our observations came to support many important previous studies. For instance, Bruzzi et al. have clearly illustrated the importance of integrated CT-PET in detecting 
distant esophageal cancer metastases that can be unusual in appearance and in unexpected locations [163]. Moreover, Nguyen et al.'s results have showed (using true whole-body F-18 FDG PET/CT) that esophageal cancer had a prevalence of $7.7 \%$ of unexpected soft tissue metastasis representing a higher prevalence when compared to lymphoma or lung carcinoma; furthermore, this study has also hypothesized that limited scanning may underestimate the true extent of soft tissue metastasis since a significant percentage of these metastases (46\%) occurred outside the typical limited whole-body field of view [164]. Finally, our findings of higher possibility of isolated UM but still poor overall survival rate can also clarify what Türkyilmaz et al.'s study showed that current staging techniques alone fail to detect disseminated tumor cells in EC since survival rate were similar in patients with hematogenous metastases in different organs, whether or not they received chemotherapy [165].

Although this review is the first with this number of data, it has many limitations concerning the homogeneity of data. But it highlights a critical point in the EC. In summary, our current work of unexpected ECM across major anatomical sites strongly supports other basic and clinical studies in understanding the possible pathways of metastatic progression which have a great impact on effective cancer control strategies. Multicentric studies, experimental studies in vivo, and anatomical studies are demanded to clarify this unexpected ECM.

\section{Conclusion}

Since esophageal cancer-unexpected metastases can occur following any cancer stage, careful physical examination (skin, eye, and muscles) and full body scan (integrated CT-PET) are required in different stages of esophageal cancer. Being responsible for approximately most of EC-related deaths, understanding of EC metastasis dissemination patterns needs more extensive research studies, and these critical data is the cornerstone of optimal cancer approach and treatment.

\section{Conflicts of Interest}

The authors declare that they have no conflicts of interest.

\section{References}

[1] American Cancer Society, "Cancer Statistics Center," 2017, https://cancerstatisticscenter.cancer.org.

[2] R. L. Siegel, K. D. Miller, and A. Jemal, "Cancer statistics, 2016," CA: A Cancer Journal for Clinicians, vol. 66, no. 1, pp. 7-30, 2016.

[3] X. Ji, J. Cai, Y. Chen, and L. Q. Chen, "Lymphatic spreading and lymphadenectomy for esophageal carcinoma," World Journal of Gastrointestinal Surgery, vol. 8, no. 1, pp. 90-94, 2016.

[4] C. L. Li, F. L. Zhang, Y. D. Wang et al., "Characteristics of recurrence after radical esophagectomy with two-field lymph node dissection for thoracic esophageal cancer," Oncology Letters, vol. 5, no. 1, pp. 355-359, 2013.
[5] F. Schlottmann, A. Barbetta, B. Mungo, A. O. Lidor, and D. Molena, "Identification of the lymphatic drainage pattern of esophageal cancer with near-infrared fluorescent imaging," Journal of Laparoendoscopic \& Advanced Surgical Techniques. Part a, vol. 27, no. 3, pp. 268-271, 2016.

[6] M. I. Abbate, F. Cicchiello, S. Canova et al., "Isolated cardiac metastasis from squamous cell esophageal cancer," Tumori, vol. 101, no. 4, pp. e118-e121, 2015.

[7] R. Adyanthaya, "Multiple cutaneous metastases from esophageal adenocarcinoma," Journal of Gastrointestinal Cancer, vol. 39, no. 1-4, pp. 22-25, 2008.

[8] D. Aguiar Bujanda, U. Bohn Sarmiento, and J. Aguiar Morales, "Some unusual paraneoplastic syndromes. Case 1. Metastatic squamous cell esophageal cancer to the thumb," Journal of Clinical Oncology, vol. 21, no. 13, p. 2620, 2003.

[9] Y. Akiyama, T. Iwaya, Y. Shioi et al., "Successfully treated advanced esophageal cancer with left axillary lymph node metastasis and synchronous right breast cancer: a case report," Surgical Case Reports, vol. 1, no. 1, p. 94, 2015.

[10] A. Al-Mamgani, L. Baartman, M. Baaijens, I. de Pree, L. Incrocci, and P. C. Levendag, "Cardiac metastases," International Journal of Clinical Oncology, vol. 13, no. 4, pp. 369-372, 2008.

[11] J. Ananiev, A. A. Chokoeva, T. Stamatov et al., "The "different face" of esophageal cancer: cutaneous manifestation of visceral malignancies," Wiener Medizinische Wochenschrift (1946), vol. 165, no. 23-24, pp. 509-511, 2015.

[12] R. S. Anderson and W. J. Peeples, "Mandibular osseous metastasis from esophageal carcinoma: a case report and review of the literature," Journal of Oral and Maxillofacial Surgery, vol. 48, no. 2, pp. 188-192, 1990.

[13] D. A. Aralikatti and A. G. Nylander, "Orbital metastasis from squamous cell carcinoma of the esophagus," European Journal of Ophthalmology, vol. 16, no. 3, pp. 458-460, 2006.

[14] R. Baijal, P. Hassan, M. Jain, D. Gupta, and N. Shah, "Cutaneous metastasis in esophageal squamous cell carcinoma," Indian Journal of Medical and Paediatric Oncology, vol. 34, no. 1, pp. 42-43, 2013.

[15] O. Basaran, C. Y. Karabay, A. Guler, and C. Kirma, "Cardiac metastasis of an esophageal cancer: a rare cause of ventricular tachycardia and left ventricle outlet obstruction," Türk Kardiyoloji Derneği Arşivi, vol. 41, no. 7, p. 670, 2013.

[16] S. Basu, N. Nair, and A. M. Borges, "Squamous cell carcinoma of esophagus masquerading as solitary thyroid nodule," Indian Journal of Cancer, vol. 42, no. 4, pp. 205-207, 2005.

[17] I. Botrugno, V. Jemos, L. Cobianchi et al., "A metachronous splenic metastases from esophageal cancer: a case report," World Journal of Surgical Oncology, vol. 9, no. 1, p. 105, 2011.

[18] L. Cavanna, A. Lazzaro, E. Trabacchi, E. Anselmi, D. Vallisa, and R. P. Foroni, "Presentation of esophageal cancer with solitary splenic metastasis," American Journal of Clinical Oncology, vol. 28, no. 6, pp. 636-637, 2005.

[19] K. P. Chang, C. P. Huang, and H. Chang, "Solitary renal metastasis of esophageal squamous cell carcinoma mimicking primary renal neoplasm-a case report and literature review," BioMedicine (Taipei), vol. 6, no. 1, p. 6, 2016.

[20] C. H. Chau, W. T. Siu, and M. K. Li, "Nasal tip metastasis from esophageal carcinoma," Canadian Journal of Surgery, vol. 45, no. 3, pp. 224-225, 2002.

[21] E. D. Chen, P. Cheng, X. Q. Yan et al., "Metastasis of distal esophageal carcinoma to the thyroid with presentation 
simulating primary thyroid carcinoma: a case report and review of the literature," World Journal of Surgical Oncology, vol. 12, no. 1, p. 106, 2014.

[22] M. F. Cheng, T. C. Huang, R. F. Yen, K. Y. Tzen, and Y. W. Wu, "Left ventricle metastasis of esophageal cancer mimicking myocardial infarction in myocardial perfusion scintigraphy," International Journal of Cardiology, vol. 167, no. 6, pp. e184-e186, 2013.

[23] Y. H. Chen and C. H. Huang, "Esophageal squamous cell carcinoma with dural and bone marrow metastases," World Journal of Gastroenterology, vol. 20, no. 35, pp. 12691-12695, 2014.

[24] O. Chino, H. Makuuchi, S. Ozawa et al., "Small intestinal metastasis from esophageal squamous cell carcinoma presenting with perforated peritonitis," The Tokai Journal of Experimental and Clinical Medicine, vol. 40, no. 2, pp. 63-68, 2015.

[25] Z. Ci, Y. Dexin, W. Qi et al., "Penile and intramuscular metastases from esophageal squamous cell carcinoma: a rare case report and review of the literature," Canadian Urological Association Journal, vol. 8, no. 11-12, pp. E875-E877, 2014.

[26] M. J. Collins, T. H. Wojno, and H. E. Grossniklaus, "Metastatic esophageal carcinoma to the orbit," American Journal of Ophthalmology, vol. 127, no. 2, pp. 228-229, 1999.

[27] F. Consoli, G. Arcangeli, V. Ferrari et al., "Circulating tumor cells and cardiac metastasis from esophageal cancer: a case report," Case Reports in Oncology, vol. 4, no. 2, pp. 299-303, 2011.

[28] K. G. J. Dev, S. Nayak, and B. Sadasivan, "Unilateral renal metastases after definitive chemoradiation in squamous cell carcinoma of esophagus: a case report and review literature," Asian Journal of Oncology, vol. 2, no. 1, pp. 46-48, 2016.

[29] A. Dong, C. Zuo, Y. Wang, Z. Zhai, and W. Wen, "Isolated nasal tip metastasis from esophageal squamous cell carcinoma," Clinical Nuclear Medicine, vol. 40, no. 1, pp. 65-67, 2015.

[30] G. Doumit, W. Abouhassan, M. P. Piliang, J. M. Uchin, and F. Papay, "Scalp metastasis from esophageal adenocarcinoma: comparative histopathology dictates surgical approach," Annals of Plastic Surgery, vol. 71, no. 1, pp. 60-62, 2013.

[31] M. J. Ellis and P. J. McDonald, "Acute epidural hematoma secondary to skull metastasis from esophageal carcinoma," The Canadian Journal of Neurological Sciences, vol. 34, no. 4, pp. 491-493, 2007.

[32] M. H. Esfehani, H. Mahmoodzadeh, A. Alibakhshi, and F. Safavi, "Esophageal squamous cell carcinoma with pancreatic metastasis: a case report," Acta Medica Iranica, vol. 49, no. 11, pp. 760-762, 2011.

[33] P. R. Fontes, U. F. Teixeira, F. L. Weachter, J. A. Sampaio, and R. Furian, "A rare case of multiple skin metastases from squamous cell carcinoma of the esophagus," The American Journal of Case Reports, vol. 13, pp. 122-124, 2012.

[34] F. Gemmel, H. Roosjen, P. van der Wijk, and J. Collins, "Subcutaneous metastasis from an occult esophageal cancer detected by PET-CT," Clinical Nuclear Medicine, vol. 33, no. 12, pp. 866-867, 2008.

[35] D. M. Geukens, B. C. Vande Berg, J. Malghem, P. De Nayer, C. Galant, and F. E. Lecouvet, "Ossifying muscle metastases from an esophageal adenocarcinoma mimicking myositis ossificans," AJR. American Journal of Roentgenology, vol. 176, no. 5, pp. 1165-1166, 2001.
[36] A. Ghibour and O. Shaheen, "Breast metastasis in esophagus cancer: literature review and report on a case," Case Reports in Surgery, vol. 2016, Article ID 8121493, 4 pages, 2016.

[37] S. Gillen, M. Feith, R. Gertler et al., "Testicular metastasis from adenocarcinoma of the esophagus," The Annals of Thoracic Surgery, vol. 87, no. 3, pp. 957-959, 2009.

[38] S. S. S. Gooptu, G. Singh, and I. Ali, "Uncommon metastasis to thyroid gland presenting as a thyroid nodule," International Journal of Case Reports and Images, vol. 4, no. 11, pp. 615-618, 2013.

[39] P. Grise, H. Botto, and M. Camey, "Esophageal cancer metastatic to kidney: report of 2 cases," The Journal of Urology, vol. 137, no. 2, pp. 274-276, 1987.

[40] M. M. Haque, M. I. Kadir, S. M. Badruddoza, M. A. Alom, and M. M. Kamal, "Metastatic squamous cell carcinoma of spleen: a case report," Mymensingh Medical Journal, vol. 22, no. 2, pp. 410-412, 2013.

[41] M. H. Hedeshian, X. Wang, B. Xu, J. P. Fontaine, and F. J. Podbielski, "Subcutaneous metastasis from esophageal cancer," Asian Cardiovascular \& Thoracic Annals, vol. 14, no. 6, pp. 520-521, 2006.

[42] E. Heffernan, D. Fennelly, and C. D. Collins, "Multiple metastases to skeletal muscle from carcinoma of the esophagus detected by FDG PET-CT imaging," Clinical Nuclear Medicine, vol. 31, no. 12, pp. 810-811, 2006.

[43] F. A. Herbella, M. G. Patti, and G. F. Takassi, "Skin metastases from esophageal and esophagogastric junction cancer," Journal of Gastrointestinal Oncology, vol. 2, no. 2, pp. 104105, 2011.

[44] A. K. Hester, D. L. Johnson, and Z. T. Awad, "Spontaneous splenic rupture due to splenic metastasis of esophageal cancer," The American Surgeon, vol. 76, no. 9, p. 1025, 2010.

[45] C. M. Heyer, G. J. Rduch, P. Zgoura, U. Stachetzki, E. Voigt, and V. Nicolas, "Metastasis to skeletal muscle from esophageal adenocarcinoma," Scandinavian Journal of Gastroenterology, vol. 40, no. 8, pp. 1000-1004, 2005.

[46] T. C. Hsieh, Y. C. Wu, S. S. Sun, C. F. Yang, and C. H. Kao, "Parotid gland metastasis from squamous cell carcinoma of esophagus detected by FDG PET/CT," Clinical Nuclear Medicine, vol. 37, no. 10, pp. 1001-1002, 2012.

[47] K. F. L. S. Hsu, C. L. Ho, J. S. Jin, Y. M. Chang, and C. Tzao, "Abdominal subcutaneous metastasis from esophageal squamous cell carcinoma," Journal of Medical Sciences, vol. 29, no. 4, pp. 217-219, 2009.

[48] Y. Ichiki, M. Morita, K. Yano, K. Sugio, K. Yasumoto, and N. Hirose, "Iris metastasis of esophageal cancer," The Annals of Thoracic Surgery, vol. 79, no. 5, pp. 1782-1784, 2005.

[49] F. Ide, T. Shimoyama, H. Haga, and N. Horie, "Basaloid squamous cell carcinoma of the esophagus metastatic to the gingiva: a case report," Oral Surgery, Oral Medicine, Oral Pathology, Oral Radiology, and Endodontics, vol. 83, no. 5, pp. 584-587, 1997.

[50] Y. Imauchi, K. Kaga, K. Nibu, N. Sakuma, Y. Iino, and K. Kodera, "Metastasis of cervical esophageal carcinoma to the temporal bone-a study of the temporal bone histology," Auris, Nasus, Larynx, vol. 28, no. 2, pp. 169172, 2001.

[51] J. Cincibuch, M. Myslivecek, B. Melichar et al., "Metastases of esophageal carcinoma to skeletal muscle: single center experience," World Journal of Gastroenterology, vol. 18, no. 35, pp. 4962-4966, 2012. 
[52] G. B. Iwanski, A. Block, G. Keller et al., "Esophageal squamous cell carcinoma presenting with extensive skin lesions: a case report," Journal of Medical Case Reports, vol. 2, p. 115, 2008.

[53] H. Iwase, T. Indo, M. Shimada et al., "Esophageal cancer with colonic metastasis successfully treated by chemoradiotherapy followed by chemotherapy with S-1 and cisplatin," International Journal of Clinical Oncology, vol. 9, no. 5, pp. 398-402, 2004.

[54] S. Jena, S. Bhattacharya, A. Gupta, S. Roy, and N. K. Sinha, "Breast metastasis from esophagogastric junction cancer: a case report," Case Reports in Surgery, vol. 2014, Article ID 489427, 4 pages, 2014.

[55] C. H. Kao, C. T. Shang, Y. C. Lin, Y. F. Li, and Y. L. Cheng, "Esophageal carcinoma presented with a skull tumour," Canadian Journal of Surgery, vol. 52, no. 5, pp. E215-E216, 2009.

[56] M. Kataoka, K. Shigemitsu, S. Tanabe, T. Ohara, T. Takahata, and S. Nose, "Sudden death from metastatic esophageal cancer to the ventricular septum," The Japanese Journal of Thoracic and Cardiovascular Surgery, vol. 53, no. 7, pp. 365-368, 2005.

[57] A. Kato, K. I. Mafune, J. Kuroda et al., "A case of esophageal cancer with mesojejunal lymph node metastasis after total gastrectomy," Esophagus, vol. 8, no. 4, pp. 311-314, 2011.

[58] V. Khurana and T. Singh, "Percutaneous endoscopic gastrostomy site metastasis in esophageal cancer," Gastrointestinal Endoscopy, vol. 62, no. 4, p. 612, 2005.

[59] Y. Kimura, M. Miyazaki, H. Saeki, T. Ohga, T. Nozoe, and K. Sugimachi, "Solitary splenic metastasis derived from esophageal cancer," Hepato-Gastroenterology, vol. 50, no. 53, pp. 1336-1337, 2003.

[60] J. Knezevic, N. Radovanovic, A. Simic et al., "Isolated choroidal metastasis from primary adenocarcinoma of the distal esophagus: a case report," Diseases of the Esophagus, vol. 16, no. 1, pp. 41-43, 2003.

[61] T. Koyama, K. Hashimoto, K. Yamaguchi, and H. Fukuda, "Esophageal carcinoma metastatic centrally to the mandible: a case report with implication of cell proliferating marker Ki-67," Journal of Oral and Maxillofacial Surgery, vol. 55, no. 6, pp. 640-645, 1997.

[62] O. N. Kozyreva, D. A. Mezentsev, D. R. King, C. R. GomezFernandez, B. Ardalan, and A. S. Livingstone, "Asymptomatic muscle metastases from esophageal adenocarcinoma," Journal of Clinical Oncology, vol. 25, no. 24, pp. 3780-3783, 2007.

[63] J. H. Ku, H. K. Park, E. Lee, D. S. Heo, and H. H. Kim, "Solitary squamous cell carcinoma in the kidney after metachronous development of esophageal and lung cancer," Tumori, vol. 91, no. 1, pp. 93-95, 2005.

[64] Y. C. L. J. Lai, P. C. Lin, W. S. Wang, and Y. C. Chen, "Esophageal squamous cell carcinoma with solitary renal metastasisa case report," Journal of Gastroenterology and Hepatology Research., vol. 1, no. 9, pp. 230-232, 2012.

[65] K. P. Lawes, M. Danford, and S. Di Palma, "Delayed metastasis to the mandible of esophageal adenocarcinoma," Head and Neck Pathology, vol. 7, no. 4, pp. 416-420, 2013.

[66] G. J. Ledderose and A. S. Englhard, "Isolated nasal tip metastasis from esophageal squamous cell carcinoma: case report and literature review," Case Reports in Otolaryngology, vol. 2015, Article ID 246094, 4 pages, 2015.
[67] K. Orlicka, S. Maynard, and M. Bouin, "Unusual presentation of a metastatic esophageal carcinoma," Case Reports in Gastroenterology, vol. 6, no. 2, pp. 273-278, 2012.

[68] J. Lee, S. Lee, J. Sohn, and Y. H. Yoon, "Clinical features of uveal metastases in Korean patients," Retina, vol. 23, no. 4, pp. 491-494, 2003.

[69] J. M. Lekse, J. Zhang, and L. A. Mawn, "Metastatic gastroesophageal junction adenocarcinoma to the extraocular muscles," Ophthalmology, vol. 110, no. 2, pp. 318-321, 2003.

[70] J. Levin, L. Ogden, and B. Karnath, "Multiple cutaneous nodules presenting as metastatic squamous cell carcinoma of the esophagus," Dermatology Online Journal, vol. 19, no. 5, p. 18173, 2013.

[71] D. H. Lim, Y. H. Im, S. H. Ji et al., "Esophageal squamous cell carcinoma recurring as a solitary renal mass," Cancer Research and Treatment, vol. 36, no. 4, pp. 271-274, 2004.

[72] J. Lindenmann, F. Gollowitsch, V. Matzi, C. Porubsky, A. Maier, and F. M. Smolle-Juettner, "Occult solitary submucosal jejunal metastasis from esophageal carcinoma," World Journal of Surgical Oncology, vol. 3, no. 1, p. 44, 2005.

[73] J. Lindenmann, V. Matzi, C. Porubsky, A. Maier, and F. M. Smolle-Juettner, "Complete resection of an isolated chest wall metastasis from esophageal carcinoma after transhiatal esophagectomy and gastric pull-up at one and a half-year follow-up," Journal of Thoracic Oncology, vol. 2, no. 8, pp. 773-776, 2007.

[74] M. Maeda, T. Goto, M. Harigai, T. Itoh, T. Moriki, and T. Miyashita, "Myocardial metastasis from squamous cell carcinoma of the esophagus," General Thoracic and Cardiovascular Surgery, vol. 57, no. 8, pp. 440-445, 2009.

[75] G. N. Magrath, C. M. Proctor, W. A. Reardon, K. G. Patel, E. J. Lentsch, and A. S. Eiseman, "Esophageal adenocarcinoma and urothelial carcinoma orbital metastases masquerading as infection," Orbit, vol. 34, no. 1, pp. 51-55, 2015.

[76] Y. S. Mao, M. Suntharalingam, and M. J. Krasna, "Management of late distant metastases after trimodality therapy for esophageal cancer," The Annals of Thoracic Surgery, vol. 76, no. 5, pp. 1742-1743, 2003.

[77] S. S. Masamatti, A. B. Pandav, M. P. Kulkarni, and K. R. Sulhyan, "Gastroesophageal junction adenocarcinoma metastasizing to gingiva," International Journal of Applied and Basic Medical Research, vol. 3, no. 1, pp. 69-71, 2013.

[78] T. Matsutani, T. Nomura, N. Hagiwara et al., "Laparoscopic diagnosis for spermatic cord metastasis from esophageal squamous cell carcinoma: report of a case," Journal of Nippon Medical School, vol. 82, no. 6, pp. 304-307, 2015.

[79] D. N. Mehta, D. N. Bailoor, V. M. Tarsariya, and B. P. Parikh, "From esophagus to gingiva: a rare case of metastatic adenocarcinoma," Journal of Oral and Maxillofacial Pathology, vol. 16, no. 3, pp. 428-431, 2012.

[80] K. Miyoshi, S. Fuchimoto, T. Ohsaki et al., "A case of esophageal squamous cell carcinoma metastatic to the breast," Breast Cancer, vol. 6, no. 1, pp. 59-61, 1999.

[81] A. Mohanty, D. Dutta, S. Das, D. R. Samanta, and S. Senapati, "Carcinoma esophagus with isolated metatarsal metastasis," Indian Journal of Cancer, vol. 48, no. 1, pp. 112-113, 2011.

[82] F. Moreno Racionero, A. B. de Andres, M. Bedate Nunez et al., "Unusual relationship between skin lesions and esophageal cancer: a case report and review of literature," Zeitschrift für Gastroenterologie, vol. 53, no. 2, pp. 115119, 2015. 
[83] P. G. Morris, J. Oda, M. H. Heinemann, and D. H. Ilson, "Choroidal metastases from esophageal adenocarcinoma responding to chemotherapy with cisplatin and irinotecan," Journal of Clinical Oncology, vol. 28, no. 22, pp. e372-e373, 2010.

[84] A. Moulick, P. Guha, A. Das, and A. K. Das, "Squamous cell carcinoma of proximal esophagus with simultaneous metastases to thyroid and sternum: a case report and review of the literature," Tanaffos, vol. 11, no. 1, pp. 67-70, 2012.

[85] S. R. Mousavi, A. Ghasemi, and A. Tajodini, "Tajodini a metastasis of esophageal cancer to finger," Archives of Iranian Medicine, vol. 8, no. 3, pp. 319-320, 2005.

[86] P. Mukker, A. Haridas, N. Kallinkeel, and P. G. Ajith, "A case report of extensive skin metastases from squamous cell carcinoma of lower esophagus and short review of literature," International Journal of Research in Medical Sciences, vol. 4, no. 5, pp. 1735-1738, 2016.

[87] Y. Nakamura, K. Nakano, A. Gomi et al., "A metastatic ball tumor in the right atrium originating from esophageal cancer: report of a case," Surgery Today, vol. 35, no. 2, pp. 145-148, 2005.

[88] N. Nakazawa, M. Fukuchi, S. Sakurai et al., "Mucosal esophageal squamous cell carcinoma with intramural gastric metastasis invading liver and pancreas: a case report," International Surgery, vol. 99, no. 4, pp. 458-462, 2014.

[89] M. A. Tunio, M. AlAsiri, M. M. Fareed, and N. M. Ali, "Tongue metastasis as an initial manifestation of distant metastasis in oesophageal adenocarcinoma," Pakistan Journal of Medical Sciences, vol. 30, no. 4, pp. 920-923, 2014.

[90] H. Narendra and S. Ray, "Numb chin syndrome as a manifestation of metastatic squamous cell carcinoma of esophagus," Journal of Cancer Research and Therapeutics, vol. 5, no. 1, pp. 49-51, 2009.

[91] M. Nielsen, J. A. Andersen, F. W. Henriksen et al., "Metastases to the breast from extramammary carcinomas," Acta Pathologica et Microbiologica Scandinavica. Section $a$, vol. 89, no. 4, pp. 251-256, 1981.

[92] M. T. Norooz, L. Montaser-Kouhsari, H. Ahmadi, M. J. Zavarei, and P. Daryaei, "Breast mass as the initial presentation of esophageal carcinoma: a case report," Cases Journal, vol. 2, no. 1, p. 7049, 2009.

[93] W. E. Norris, J. L. Perry, F. J. Moawad, and J. D. Horwhat, "An unusual presentation of metastatic esophageal adenocarcinoma presenting as thigh pain," Journal of Gastrointestinal and Liver Diseases, vol. 18, no. 3, pp. 371-374, 2009.

[94] H. Okamoto, Y. Hara, M. Chin et al., "An extremely rare case of pancreatic metastasis of esophageal squamous cell carcinoma," World Journal of Gastroenterology, vol. 20, no. 2, pp. 593-597, 2014.

[95] S. M. Oliveira, A. Goncalves, C. Cruz et al., "Cardiac metastasis from epidermoid esophageal cancer mimicking anterior myocardial infarction," Revista Portuguesa de Cardiologia, vol. 31, no. 2, pp. 163-166, 2012.

[96] T. Ono, S. Motoyama, R. Saito, M. Okuyama, H. Imano, and J. Ogawa, "Mesojejunal lymph node metastasis in esophageal cancer following total gastrectomy," The Japanese Journal of Thoracic and Cardiovascular Surgery, vol. 52, no. 11, pp. 542-544, 2004.

[97] A. Pai, S. Sonawane, N. C. Purandare et al., "Penile metastasis from esophageal squamous carcinoma after curative resection," Annals of Thoracic and Cardiovascular Surgery, vol. 14, no. 4, pp. 238-241, 2008.

[98] D. Pal, A. Bahl, J. B. Sharma, and R. R. Rao, "Carcinoma esophagus: a rare primary malignancy for ocular metastasis," Indian Journal of Cancer, vol. 47, no. 4, pp. 480-481, 2010.

[99] H. K. Parikh, R. K. Deshpande, D. V. Swaroop, and P. B. Desai, "Choroidal metastasis from primary adenocarcinoma of the esophagus-a case report," Indian Journal of Cancer, vol. 29, no. 4, pp. 210-214, 1992.

[100] C. Park, J. Y. Jang, Y. H. Kim et al., "A case of esophageal squamous cell carcinoma with pancreatic metastasis," Clinical Endoscopy, vol. 46, no. 2, pp. 197-200, 2013.

[101] J. M. Park, D. S. Kim, S. H. Oh, Y. S. Kwon, and K. H. Lee, "A case of esophageal adenocarcinoma metastasized to the scalp," Annals of Dermatology, vol. 21, no. 2, pp. 164-167, 2009.

[102] D. C. Pedraza, J. Santos-Juanes, D. C. Fernandez, and A. Perez-Arias, "Cutaneous metastasis in the face as the first manifestation of esophageal adenocarcinoma: case report and literature review," European Journal of Plastic Surgery, vol. 38, no. 2, pp. 147-152, 2015.

[103] H. M. Pollack, M. P. Banner, and M. A. Amendola, "Other malignant neoplasms of the renal parenchyma," Seminars in Roentgenology, vol. 22, no. 4, pp. 260-274, 1987.

[104] A. D. Puranik, N. C. Purandare, S. Sawant et al., "Asymptomatic myocardial metastasis from cancers of upper aerodigestive tract detected on FDG PET/CT: a series of 4 cases," Cancer Imaging, vol. 14, no. 1, p. 16, 2014.

[105] J. Purkayastha, "Isolated bony metastasis to upper limb from carcinoma of the oesophagus: report of three cases," Hand (N Y)., vol. 10, no. 1, pp. 137-139, 2015.

[106] S. U. Rehman, D. W. Cope, and J. N. Basile, "Metastatic gastroesophageal adenocarcinoma to skeletal muscle: a unique event," Southern Medical Journal, vol. 95, no. 9, pp. 1076-1078, 2002.

[107] M. Rivas-Rivas, D. Jimenez-Gallo, N. Navas-Garcia, C. Albarran-Planelles, and C. Rodriguez-Ramos, "Skin metastases as initial manifestation of esophageal squamous-cell carcinoma," Revista Española de Enfermedades Digestivas, vol. 105, no. 10, pp. 624-625, 2013.

[108] S. Marupaka, S. Modi, and S. Singh, "Esophageal cancer: presentation with unusual bone metastases and review of relevant literature," The Internet Journal of Gastroenterology, vol. 5, no. 1, 2006.

[109] E. K. Roh, R. Nord, and D. M. Jukic, "Scalp metastasis from esophageal adenocarcinoma," Cutis, vol. 77, no. 2, pp. 106-108, 2006.

[110] A. D. Roy, M. Sherparpa, P. R. Prasad, and R. Lamichanet, "Scalp metastasis of gastro-esophageal junction adenocarcinoma: a rare occurrence," Journal of Clinical and Diagnostic Research, vol. 8, no. 2, pp. 159-160, 2014.

[111] J. Samuel, T. P. Flood, B. Agbemadzo et al., "Choroidal metastasis from adenocarcinoma of the esophagus," Retina, vol. 23, no. 6, pp. 874-877, 2003.

[112] J. Sanchez-Jimenez, F. Acebal-Blanco, R. E. Arevalo-Arevalo, and M. Molina-Martinez, "Metastatic tumours in upper maxillary bone of esophageal adenocarcinoma. A case report," Medicina Oral, Patología Oral y Cirugía Bucal, vol. 10, no. 3, pp. 252-257, 2005.

[113] D. A. Santeufemia, G. Piredda, G. M. Fadda et al., "Successful outcome after combined chemotherapeutic and surgical management in a case of esophageal cancer with breast and 
brain relapse," World Journal of Gastroenterology, vol. 12, no. 34, pp. 5565-5568, 2006.

[114] S. Sanyal, L. Kaman, and S. K. Sinha, "Splenic metastasis from esophageal cancer: report of a case," Surgery Today, vol. 35, no. 11, pp. 988-990, 2005.

[115] T. Sawada, Y. Adachi, M. Noda et al., "Hepatic portal venous gas in pancreatic solitary metastasis from an esophageal squamous cell carcinoma," Hepatobiliary \& Pancreatic Diseases International, vol. 12, no. 1, pp. 103-105, 2013.

[116] J. M. Schoneveld, W. L. Hesp, and T. M. Teune, "Parotid metastasis from a gastroesophageal carcinoma: report of a case," Digestive Surgery, vol. 24, no. 1, pp. 68-69, 2007.

[117] S. R. Schultz, R. L. Bree, R. E. Schwab, and G. Raiss, "CT detection of skeletal muscle metastases," Journal of Computer Assisted Tomography, vol. 10, no. 1, pp. 81-83, 1986.

[118] J. M. Schuster, R. C. Rostomily, C. Hahn, and H. R. Winn, "Two cases of esophageal carcinoma metastatic to the pineal region with a review of the literature," Surgical Neurology, vol. 49, no. 1, pp. 100-103, 1998.

[119] C. L. Shields, J. F. McMahon, H. T. Atalay, M. Hasanreisoglu, and J. A. Shields, "Retinal metastasis from systemic cancer in 8 cases," JAMA Ophthalmology, vol. 132, no. 11, pp. 13031308, 2014

[120] M. Shiraishi, T. Itoh, K. Furuyama et al., "Case of metastatic breast cancer from esophageal cancer," Diseases of the Esophagus, vol. 14, no. 2, pp. 162-165, 2001.

[121] R. Silfen, A. Amir, A. Tobar, and D. J. Hauben, "The digital pulp as a presenting site of metastatic esophageal carcinoma," Annals of Plastic Surgery, vol. 46, no. 2, pp. 183-184, 2001.

[122] D. Singh, A. Sharma, B. Arora, N. K. Shukla, and B. K. Mohanti, "Adenocarcinoma esophagus with choroid metastasis," Indian Journal of Gastroenterology, vol. 23, no. 3, pp. 112-113, 2004.

[123] K. J. Smith, J. Williams, and H. Skelton, "Metastatic adenocarcinoma of the esophagus to the skin: new patterns of tumor recurrence and alternate treatments for palliation," Journal of Cutaneous Pathology, vol. 28, no. 8, pp. 425-431, 2001.

[124] S. P. Smith, K. Grossman, B. K. Rao, H. K. Koh, and T. D. Cooley, "Solitary papule of the lip in recurrent gastroesophageal carcinoma: an unusual presentation of cutaneous metastasis," Archives of Dermatology, vol. 127, no. 4, pp. 588-589, 1991.

[125] J. W. Smoleroff and S. A. Agatston, "Metastatic carcinoma of the retina: report of a case, with pathologic observations," Archives of Ophthalmology, vol. 12, no. 3, pp. 359-365, 1934.

[126] M. Sokolosky Jr., J. E. Bouquot, and R. W. Graves, "Esophageal carcinoma metastatic to the oral cavity," Journal of Oral and Maxillofacial Surgery, vol. 44, no. 10, pp. 825-827, 1986.

[127] T. Dam, A. Mahmood, K. Linville, M. Bailey, and S. Surani, "Meningeal carcinomatosis: a metastasis from gastroesophageal junction adenocarcinoma," Case Reports in Medicine, vol. 2013, Article ID 245654, 4 pages, 2013.

[128] R. H. Stein and J. M. Spencer, "Painful cutaneous metastases from esophageal carcinoma," Cutis, vol. 70, no. 4, pp. 230232, 2002.

[129] B. Struijs, R. de Bree, C. J. van Groeningen, W. J. Mooi, and C. R. Leemans, "Tonsillar metastasis of oesophageal adenocarcinoma," European Archives of Oto-Rhino-Laryngology, vol. 265, no. 1, pp. 127-129, 2008.
[130] I. Sufyan, S. A. Edaigbini, A. A. Liman, M. B. Aminu, and I. Z. Delia, "Esophageal carcinoma presenting with cutaneous nodules," Sub-Saharan African Journal Medicine, vol. 1, pp. 153-156, 2014.

[131] Y. Sun, X. Yu, and Y. Zhang, "Renal metastasis after esophagectomy of esophageal squamous cell carcinoma: a case report and literature review," World Journal of Surgical Oncology, vol. 12, p. 165, 2014.

[132] M. Tamatey, L. Sereboe, M. Tettey, K. Entsua-mensah, and B. Gyan, "Cutaneuos metastasis of carcinoma of the oesophagus to the left shoulder: a case report," Annales africaines de chirurgie thoracique et cardio-vasculaire, vol. 7, no. 1, 2012.

[133] D. Tamiolakis, I. Tsamis, V. Thomaidis et al., "Oral complaints caused from metastases to the mandible and maxilla," Chirurgia (Bucur), vol. 102, no. 4, pp. 439-442, 2007.

[134] T. Tatai, S. Sasaki, N. Sekiguchi, and T. Koizumi, "Iris metastasis of esophageal cancer," Internal Medicine, vol. 54, no. 15, p. $1941,2015$.

[135] H. Tideman, J. F. Arvier, A. G. Bosanquet, and D. F. Wilson, "Esophageal adenocarcinoma metastatic to the maxilla," Oral Surgery, Oral Medicine, and Oral Pathology, vol. 62, no. 5, pp. 564-568, 1986.

[136] S. Triantafyllou, D. Georgia, V. Gavriella-Zoi et al., "Cutaneous metastases from esophageal adenocarcinoma," International Surgery, vol. 100, no. 3, pp. 558-561, 2015.

[137] K. Tumuluri, E. Sharkawi, M. Bindra, and J. M. Olver, "Esophageal adenocarcinoma metastatic to the orbit," Ophthalmic Plastic and Reconstructive Surgery, vol. 22, no. 2, pp. 151-152, 2006.

[138] H. Tuna, M. Bozkurt, C. Sarilar, A. O. Heper, and A. Erdogan, "Esophageal carcinoma metastasis to cerebellum: a case report," Turkish Neurosurgery, vol. 18, no. 1, pp. 65-69, 2008.

[139] J. N. Ulrich, S. Garg, G. K. Escaravage Jr., and T. M. Meredith, "Bilateral diffuse uveal melanocytic proliferation presenting as small choroidal melanoma," Case Reports in Ophthalmological Medicine, vol. 2011, Article ID 740640, 3 pages, 2011.

[140] Y. Umebayashi, "Metastasis of esophageal carcinoma manifesting as whitlow-like lesions," The Journal of Dermatology, vol. 25, no. 4, pp. 256-259, 1998.

[141] V. Vidovic, I. Nikolic, J. Vukojevic et al., "Unusual metastasis of esophageal cancer," Vojnosanitetski Pregled, vol. 71, no. 10, pp. 975-977, 2014.

[142] M. Wang, J. Patel, T. T. Casey, R. Kieffer, and G. D. Dunn, "Metastatic squamous cell carcinoma from the esophagus occurring as small bowel obstruction," Southern Medical Journal, vol. 78, no. 7, pp. 884-886, 1985.

[143] C. C. Willard, C. R. Weber, and W. Buche, "Metastatic esophageal adenocarcinoma involving the maxilla," Journal of Oral and Maxillofacial Surgery, vol. 60, no. 12, pp. 1496-1499, 2002.

[144] G. Wu, B. Bybel, R. Brunken, H. Lin, and D. Neumann, "PET detection of solitary distant skeletal muscle metastasis of esophageal adenocarcinoma," Clinical Nuclear Medicine, vol. 30, no. 5, pp. 335-337, 2005.

[145] T. Yamada, S. Yagi, Y. Tatsuzawa et al., "Small intestinal metastasis from esophageal carcinoma associated with small intestinal obstruction: report of a case," Surgery Today, vol. 26, no. 10, pp. 800-802, 1996.

[146] P. H. Yathiraj, A. Patil, and S. Ghosh-Laskar, "Nasal mucosal metastasis in a case of carcinoma esophagus: case report and 
review of literature," Journal of Cancer Research and Therapeutics, vol. 11, no. 3, p. 655, 2015.

[147] Z. X. Ye, C. M. Hsueh, H. B. Leu, and J. W. Chen, "Recurrence of esophageal cancer presents as transient ischemic attack," Journal of the Chinese Medical Association, vol. 74, no. 4, pp. 176-178, 2011.

[148] L. Ye-huan, L. Shi-xu, Z. Yi-li, W. Ou-chen, and Z. Xiaohua, "Unexpected esophageal diseases appeared in thyroid resections," World Journal of Surgical Oncology, vol. 13, p. 131, 2015.

[149] H. J. Youn, S. E. Jung, W. S. Chung et al., "Obstruction of right ventricular outflow tract by extended cardiac metastasis from esophageal cancer," Journal of the American Society of Echocardiography, vol. 15, no. 12, pp. 1541-1544, 2002.

[150] S. Datta, J. A. Munoz-Largacha, L. Li, G. Q. Zhao, and V. R. Litle, "Subcutaneous metastases from early stage esophageal adenocarcinoma case report," International Journal of Surgery Case Reports, vol. 29, pp. 108-112, 2016.

[151] M. K. Na, C. H. Kim, J. M. Kim, J. W. Cheong, J. I. Ryu, and H. W. Kim, "Multiple meningocerebral metastasis and extensive skull metastasis from squamous cell carcinoma of esophagus: a case report and review of literature," Brain Tumor Research and Treatment, vol. 4, no. 2, pp. 142144, 2016.

[152] S. Pokharel, G. Kabbach, S. J. Richter, and L. Chiu, "Metastatic esophageal cancer presenting as an orbital mass," ACG Case Reports Journal, vol. 3, no. 4, article e154, 2016.

[153] S. Tsutsumi, H. Saeki, Y. Nakashima et al., "Distant lymph node metastases caused by esophageal cancer invasion to the lamina propria: a case report," Surgical Case Reports, vol. 2, no. 1, p. 143, 2016.

[154] C. L. Chaffer and R. A. Weinberg, "A perspective on cancer cell metastasis," Science, vol. 331, no. 6024, pp. 15591564, 2011.

[155] G. P. Gupta and J. Massague, "Cancer metastasis: building a framework," Cell, vol. 127, no. 4, pp. 679-695, 2006.

[156] T. J. Weijs, L. Goense, P. S. van Rossum et al., "The peri-esophageal connective tissue layers and related compartments: visualization by histology and magnetic resonance imaging," Journal of Anatomy, vol. 230, no. 2, pp. 262-271, 2017.

[157] H. Akiyama, M. Tsurumaru, H. Udagawa, and Y. Kajiyama, "Radical lymph node dissection for cancer of the thoracic esophagus," Annals of Surgery, vol. 220, no. 3, pp. 364-373, 1994.

[158] X. Ding, J. Zhang, B. Li et al., "A meta-analysis of lymph node metastasis rate for patients with thoracic oesophageal cancer and its implication in delineation of clinical target volume for radiation therapy," The British Journal of Radiology, vol. 85, no. 1019, pp. e1110-e1119, 2012.

[159] R. Maingot, M. Zinner, and S. W. Ashley, Maingot's Abdominal Operations, McGraw-Hill Medical; London: McGraw-Hill (distributor), New York, 11 edition, 2007.

[160] E. S. Gray, "Arterial or venous: where are the circulating tumor cells?" eBioMedicine, vol. 2, no. 11, pp. 15961597, 2015.

[161] J. E. Skandalakis and G. L. Colborn, Skandalakis' Surgical Anatomy: The Embryologic and Anatomic Basis of Modern Surgery, PMP; [London: McGraw-Hill] [distributor], Athens, Greece, 2004.
[162] J. Budczies, M. von Winterfeld, F. Klauschen et al., “The landscape of metastatic progression patterns across major human cancers," Oncotarget, vol. 6, no. 1, pp. 570-583, 2015.

[163] J. F. Bruzzi, M. T. Truong, H. Macapinlac, R. F. Munden, and J. J. Erasmus, "Integrated CT-PET imaging of esophageal cancer: unexpected and unusual distribution of distant organ metastases," Current Problems in Diagnostic Radiology, vol. 36, no. 1, pp. 21-29, 2007.

[164] N. C. Nguyen, B. T. Chaar, and M. M. Osman, "Prevalence and patterns of soft tissue metastasis: detection with true whole-body F-18 FDG PET/CT," BMC Medical Imaging, vol. 7, p. 8, 2007.

[165] A. Türkyilmaz, A. Eroğlu, Y. Aydin, Ö. Yilmaz, and N. Karaoğlanoğlu, "Survival in esophageal cancer patients with hematogenous distant organ metastases," Turkish Journal of Medical Sciences., vol. 39, no. 3, pp. 415-421, 2009. 


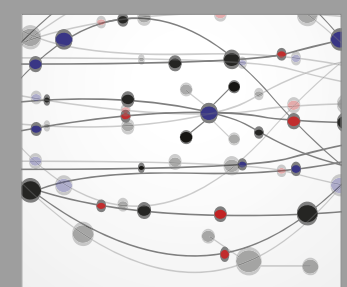

The Scientific World Journal
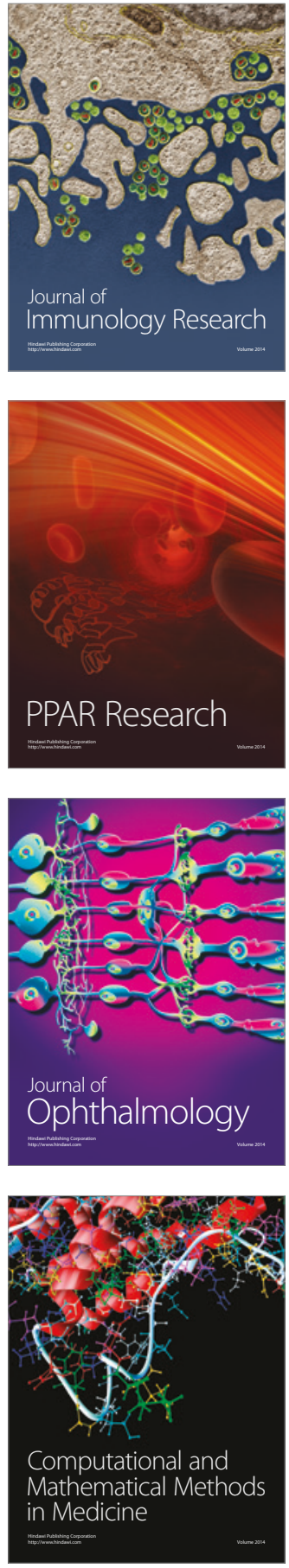

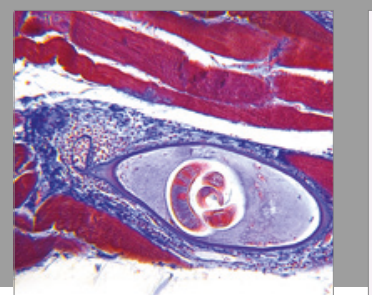

Gastroenterology Research and Practice
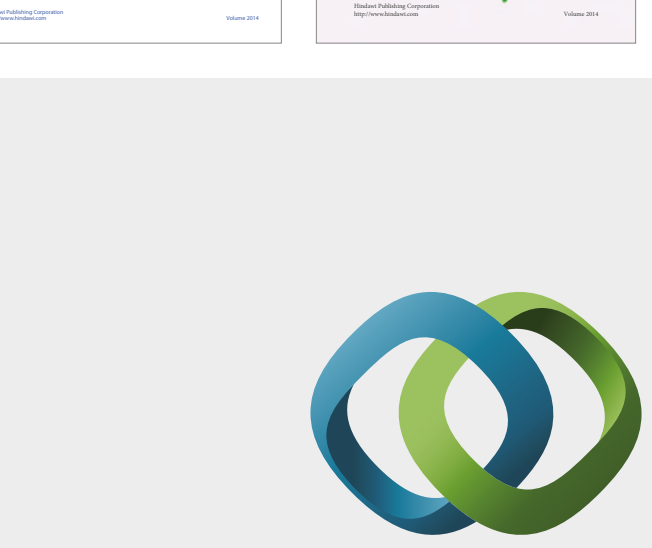

\section{Hindawi}

Submit your manuscripts at

https://www.hindawi.com
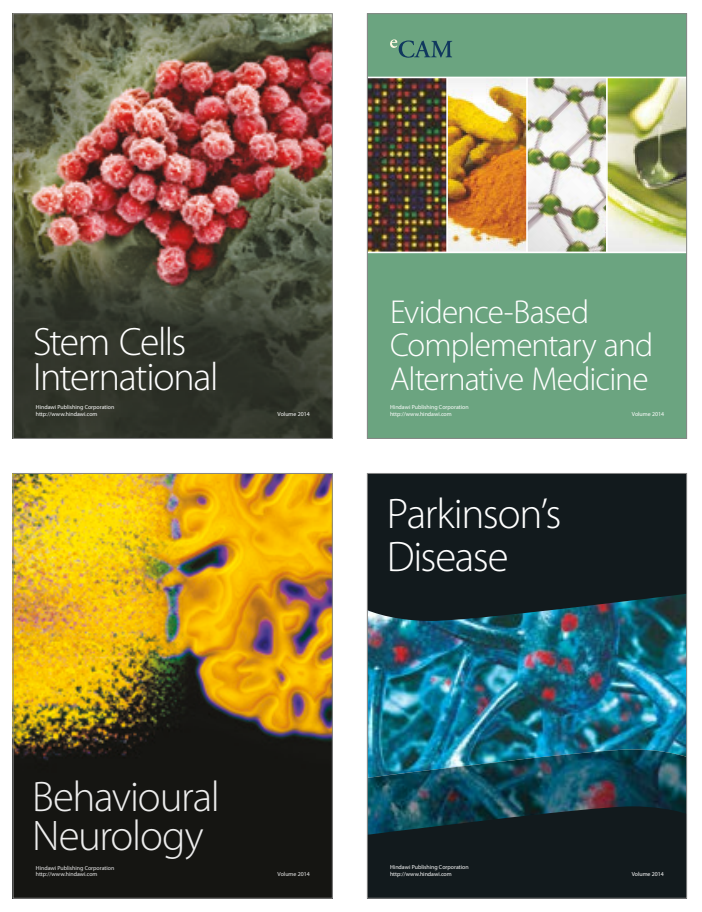
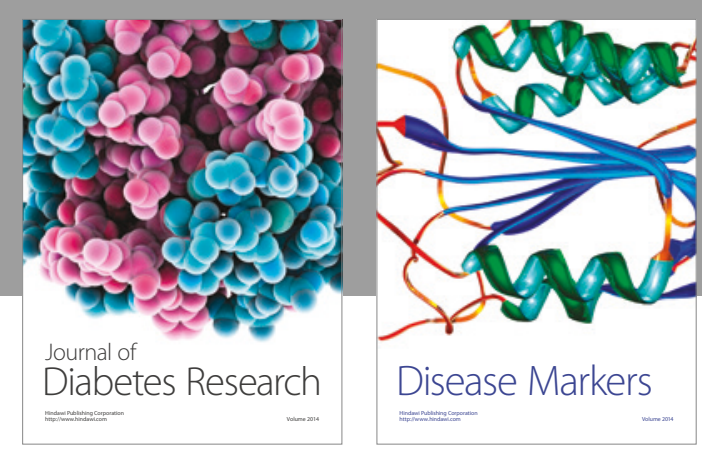

Disease Markers
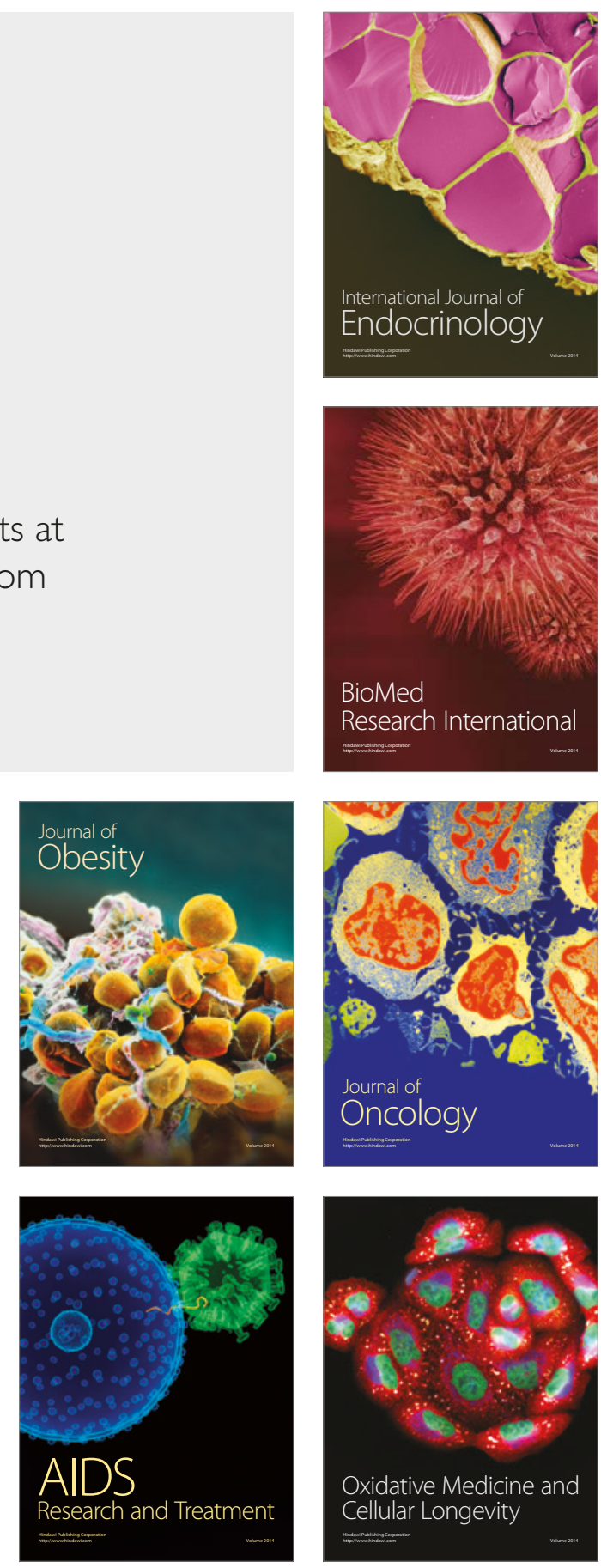